\title{
A Slowly Inactivating Potassium Current in CA3 Pyramidal Cells of Rat Hippocampus In Vitro
}

\author{
Anita Lüthi, Beat H. Gähwiler, and Urs Gerber \\ Brain Research Institute, University of Zürich, CH-8029 Zürich, Switzerland
}

The time- and voltage-dependent properties of a slowly inactivating $\mathrm{K}^{+}$current were investigated by using the single-electrode current- and voltage-clamp recording technique in $\mathrm{CA} 3$ hippocampal cells of organotypic slice cultures. After a period of prolonged hyperpolarization, the onset of action-potential discharge in response to depolarizing current injection was delayed by several seconds. The conductances underlying this delay were identified in voltage-clamp recordings. A biphasically decaying outward current was evoked when the membrane potential was stepped back to $-60 \mathrm{mV}$ after a $30 \mathrm{sec}$ period of hyperpolarization. The fast component was identified as the previously described D-current and was blocked by $100 \mu \mathrm{M}$ 4-aminopyridine (4-AP). The slow comporient, which we refer to as $I_{K \text { (slow) }}$, appeared to be mediated by $\mathrm{K}^{+}$ions, because its reversal potential shifted in a Nernstian manner with changes in extracellular $\mathrm{K}^{+}$ concentration. It decayed with a time constant of $7.5 \mathrm{sec}$ and required a hyperpolarizing prepulse below $-95 \mathrm{mV}$ for $5.5 \mathrm{sec}$ for
$50 \%$ recovery from inactivation. $I_{\mathrm{K}(\mathrm{slow})}$ was found to be voltagedependent, with $50 \%$ activation occurring at $-65 \mathrm{mV}$ and $50 \%$ steady-state inactivation occurring at $-84 \mathrm{mV}$. It displayed minimal or no sensitivity to the $\mathrm{K}^{\prime}$-channel blockers 4-AP $(0.1-5 \mathrm{~mm})$, $\mathrm{Cs}^{+}(1 \mathrm{~mm})$, tetraethylammonium $(10-50 \mathrm{~mm}), \mathrm{Ba}^{2+}(1 \mathrm{~mm})$, dendrotoxin- $\alpha(5-10 \mu \mathrm{M})$, charybdotoxin $(0.5-2.5 \mu \mathrm{M})$, or glibenclamide $(5-10 \mu \mathrm{M})$ and was not affected by preventing increases in intracellular $\mathrm{Ca}^{2+}$ concentration with $\mathrm{Ca}^{2+}$ chelators. $I_{k \text { (slow) }}$ was reduced by activation of metabotropic glutamatergic and cholinergic receptors. In summary, the biophysical characteristics of $I_{\mathrm{K} \text { (slow) }}$ suggest a role in determining discharge onset after a period of membrane hyperpolarization, and its modulation by G-proteincoupled receptors reveals an additional function for these receptors in the control of cellular excitability.

Key words: latency to discharge; transient $K^{+}$currents; $D$ current; CA3 cells; metabotropic glutamate receptors; muscarinic receptors
Voltage-dependent $\mathrm{K}^{+}$conductances are involved critically in the patterning of neuronal discharge in response to depolarizing stimuli. They contribute in determining (1) the onset of discharge, (2) the rate of action-potential repolarization, and (3) the adaptation of discharge frequency (Hille, 1992). Whereas spike repolarization and adaptation of repetitive firing have been well characterized in terms of the underlying $\mathrm{K}^{+}$conductances (Brown et al., 1990; Storm, 1993), open questions remain concerning the mechanisms that control the latency to onset of spike discharge.

Action-potential discharge episodes frequently are preceded by a slow, depolarizing ramp potential, the duration of which is a function of the degree of neuronal membrane hyperpolarization before the depolarizing input. In mammalian neurons at resting potential, the onset of action-potential discharge in response to a depolarizing input is rapid and occurs in the range of one to three membrane time constants. In contrast, cells excited after a period of hyperpolarization exhibit a delay to the first action potcntial lasting between 0.4 and $10 \mathrm{sec}$ (Byrne et al., 1979; Getting, 1983; Dekin et al., 1987; Storm, 1988; McCormick, 1991; Nisenbaum et al., 1994).

In hippocampal pyramidal cells, the control of the latency to discharge onset has been ascribed mainly to two $\mathrm{K}^{+}$currents that

Received July 27, 1995; revised Sept. 29, 1995; accepted Oct. 4, 1995

This work was supported by Grant 31-35976.92 from the Swiss National Science Foundation, by the Prof. Dr. Max Cloëtta Foundation (U.G.), and by Sandoz Pharma, Basel (A.L.). We thank Dr. D. A. Brown for his assistance in the planning of some of the experiments and for his continuing critical advice. We also thank Drs. J. L. Bossu, M. Capogna, and S. M. Thompson for many helpful comments during the course of this study. We are very grateful to L. Rietschin, L. Heeb, H. Kasper, R. Schöb, and E. Hochreutener for their excellent technical assistance.

Correspondence should be addressed to Anita Lüthi, Brain Research Institute, University of Zürich, August Forel-Strasse 1, CH-8029 Zürich, Switzerland.

Copyright $\bigcirc 1996$ Society for Neuroscience $0270-6474 / 96 / 160586-09 \$ 05.00 / 0$ recover from inactivation during a hyperpolarizing pulsc. The Acurrent, first observed in molluscan neurons (Thompson, 1977) and later in guinea pig CA3 hippocampal cells (Gustafsson et al., 1982 ), is a rapidly inactivating $\mathrm{K}^{+}$current ( $\tau$ between 15 and 50 $\mathrm{msec}$ ) with an activation threshold of $-60 \mathrm{mV}$. The D-current, first studied in CA1 hippocampal cells (Storm, 1988), inactivates more slowly ( $\tau$ of several hundred milliseconds), with an activation threshold of $-75 \mathrm{mV}$. The $\mathrm{K}^{+}$-channel blocker 4-aminopyridine (4-AP) selectively blocks the A-current (1-5 mM) and D-current (30-100 $\mu \mathrm{M})$ and reduces the time-to-onset of discharge (Gustafsson et al., 1982; Storm, 1988).

In many cases, however, the A- and D-currents cannot account completely for the latency to the initiation of the first action potential. Moreover, the fact that slow transient outward currents recorded in hippocampal pyramidal cells can be fitted only adequately by multiexponential functions, including components with time constants of several seconds (Storm, 1986; Numann et al., 1987; Ficker and Heinemann, 1992), suggests the involvement of additional currents that determine the time point for the initiation of action-potential discharge.

In this study, we report on a previously undescribed current in CA3 pyramidal cells that contributes to the control of discharge onset and characterizes its biophysical and pharmacological properties.

A preliminary version of these data has been presented previously in abstract form (Lüthi et al., 1994).

\section{MATERIALS AND METHODS}

Hippocampal slice cultures. Slices $400 \mu \mathrm{m}$ thick were obtained from 4- to 6-d-old rat pups and cultured via the roller-tube technique for 3-6 weeks as described previously (Gähwiler, 1981). 
Electrophysiological recordings. The single-electrode voltage-clamp method was used to record from CA3 pyramidal celis (Axoclamp-2 amplifier, Axon Instruments, Foster City, CA). For this purpose, cultures were transferred to a temperature-controlled recording chamber that was mounted on the stage of an inverted microscope (Axiovert 35M, Zeiss, Jena, Germany) and superfused with a saline solution $\left(33^{\circ} \mathrm{C}\right)$ containing (in $\mathrm{mM}$ ): $149.2 \mathrm{Na}^{+}, 2.7 \mathrm{~K}^{+}, 147.2 \mathrm{Cl}^{-}, 2.8 \mathrm{Ca}^{2+}, 0.5 \mathrm{Mg}^{2+}, 11.6$ $\left(\mathrm{HCO}_{3}\right)^{-}, 0.4\left(\mathrm{H}_{2} \mathrm{PO}_{4}\right)^{-}$, and $5.6 \mathrm{D}$-glucose. For current-clamp recordings, the concentration of $\mathrm{Mg}^{2+}$ was raised to $5 \mathrm{~mm}$. Voltage-clamp recordings were done in the presence of tetrodotoxin (TTX; $0.5 \mu \mathrm{M}$ ). To eliminate contributions from the D-current, $0.1 \mathrm{~mm} 4$-AP was added to the bath. When $\mathrm{Cd}^{2+}$ was used, $\left(\mathrm{H}_{2} \mathrm{PO}_{4}\right)^{-}$was omitted from the saline solution. Solutions were adjusted to $\mathrm{pH} 7.4$ by bubbling with $95 \% \mathrm{O}_{2} / 5 \%$ $\mathrm{CO}_{2}$ and monitored with Phenol-red $(10 \mathrm{mg} / 1)$.

CA3 pyramidal cells were impaled with thin-walled electrodes that were filled with a solution containing $2 \mathrm{M} \mathrm{KCl}, 2 \mathrm{M} \mathrm{CsCl}$, or $1 \mathrm{M} \mathrm{KMeSO}_{4}$, resulting in a tip resistance of $30-50 \mathrm{M} \Omega$ for $\mathrm{KCl}$ and $\mathrm{CsCl}$ and $60-80$ $\mathrm{M} \Omega$ for $\mathrm{KMeSO}_{4}$. Before recording, electrodes were tested for polarization artifacts by using negative current injections of $1 \mathrm{nA}$ for $30 \mathrm{sec}$. The average polarization was $0.7 \pm 0.2 \mathrm{mV}(n=8)$. During voltage-clamp recordings, the switching rate ranged between 1.5 and $2.0 \mathrm{kHz}$, which provided sufficient resolution to analyze slow $\mathrm{K}^{+}$currents $(\tau=7.5 \mathrm{sec})$, and headstage output was monitored continuously to ensure adequate settling time between samples. Input resistance was assessed by applying $0.5 \mathrm{sec}$ hyperpolarizing voltage commands of $10 \mathrm{mV}$. Only cells for which input resistance was sufficiently high ( $>50 \mathrm{M} \Omega$ ) were studied.

Drugs were focally, iontophoretically, or bath-applied. For iontophoresis, patch electrodes filled with a solution conlaining 1-anino-cyclopentyltrans-1S,3R-dicarboxylate ( $1 S, 3 R$-ACPD; $50 \mathrm{mM}, \mathrm{pH} 9.0)$, muscarine (10 $\mathrm{mM}, \mathrm{pH} 7.0)$, or AMPA (10 mM, pH 9.0) were placed close to the recorded cell. The retaining current ranged from 30 to $200 \mathrm{nA}$, the ejection current ranged from 50 to $300 \mathrm{nA}$, and the appropriate polarity was chosen with respect to the charge of the ejected substance. The application time varied between 2 and $10 \mathrm{sec}$. Dendrotoxin- $\alpha$ (DTX) and charybdotoxin (CTX) were applied focally by application of small drops of solution $(1-10 \mu \mathrm{l})$ close to the recorded cell. Dilution factors were calculated by comparing the current responses to focally and bath-applied $(-)-\beta-p$-chlorophenyl-GABA (baclofen).

In some experiments, electrode tips were filled with $25 \mathrm{~mm}$ BAPTA and electrode shanks were back-filled with $2 \mathrm{M} \mathrm{KCl}$. Suppression of the $\mathrm{Ca}^{2+}$-dependent afterhyperpolarization current after $50 \mathrm{msec}$ depolarizing voltage commands was used as an indicator for the effectiveness of BAPTA diffusion into the cell.

Dafa recording and analysis. Voltage records were digitized at $33 \mathrm{~Hz}$ (Digidata 1200 as analog-to-digital converter, Axon Instruments, Foster City, CA), which was sufficient to provide an undistorted record of $I_{\mathrm{K} \text { (slow) }}$ $(\tau=7.5 \mathrm{sec})$. For current-clamp experiments, the digitization rate was 2 $\mathrm{kHz}$. Data were recorded using a chart recorder (Gould, Cleveland, $\mathrm{OH}$ ) and stored on-line with a PC. Acquisition and analysis were performed using pClamp version 6.0.1. (Axon) and FigP (Biosoft, Cambridge, UK) software. Quantitative data are given as mean \pm SEM. Statistical analysis was performed using Student's $t$ test.

Drugs and chemicals. 4-AP, tetraethylammonium (TEA), muscarine, acetyl- $\beta$-methylcholine chloride (methacholine, $\mathrm{MCh}$ ), and strophanthidin were purchased from Sigma (St. Louis, MO). IS,3R-ACPD and AMPA were purchased from Tocris Neuramin (Bristol, UK). DTX and CTX were from Affiniti Research Products (Nottingham, UK). Glibenclamide was from Research Biochemicals (Natick, MA). BAPTA was from Molecular Probes (Eugene, OR), and TTX was from Sankyo (Tokyo, Japan). Baclofen was donated by Ciba-Geigy (Basel, Switzerland).

\section{RESULTS}

\section{Delayed onset of firing after hyperpolarization}

Mechanisms underlying the delay in onset of action-potential discharge in response to excitatory inputs were investigated in CA3 pyramidal cells in organotypic hippocampal slice cultures. On the basis of previous studies, transient outward currents, inactivation of which is removed by hyperpolarizing prepulses, are important in determining the delay to spike onset (Storn, 1993). Therefore, experiments were designed to characterize the excitability of cells as a function of the amplitude and the duration of a hyperpolarizing prepulse. First, the threshold current required

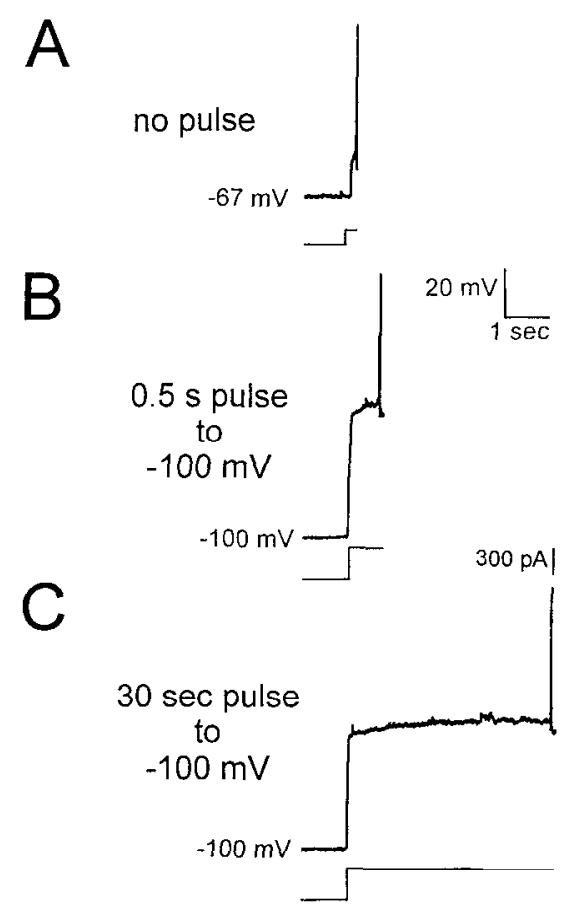

Figure 1. The delay in onset of action-potential generation is dependent on the duration of the preceding hyperpolarizing current injection. This cell had a resting potential of $-67 \mathrm{mV}$, and the threshold potential for eliciting action potentials was $-44.8 \pm 0.4 \mathrm{mV}$ ( $n=15$ current injections). Current-injection protocols are displayed below each voltage recording. $A$, Depolarizing current injection at resting potential to threshold caused rapid onset in action-potential generation. Firing onset was delayed when hyperpolarizing current prepulses were applied. $B$, Hyperpolarizing pulse of $0.5 \mathrm{sec}$ to $-100 \mathrm{mV}$. C, Pulse of $30 \mathrm{sec}$ to $-100 \mathrm{mV}$. The threshold for action-potential generation was not changed after a hyperpolarizing prepulse $(-44.4 \pm 0.2 \mathrm{vs}-44.8 \pm 0.4 \mathrm{mV}, p>0.05 ; n=12)$.

to evoke an action potential from resting potential was determined. Next, cells were hyperpolarized by current injection to potentials between -100 and $-120 \mathrm{mV}$ for various durations. Cells were then repolarized by injecting a current pulse corresponding to the absolute sum of the threshold and the hyperpolarizing current.

With this protocol, responses that depended on the parameters of the hyperpolarizing prepulse applied were elicited in CA3 pyramidal neurons. In Figure $1 A$, data are presented from a cell with a passive membrane time constant of $42 \mathrm{msec}$, as determined by monoexponential fitting of membrane voltage responses to negative current injections of $100 \mathrm{pA}$ (data not shown). When depolarized from the resting potential of $-67 \mathrm{mV}$, the latency to the first spike, measured from the onset of depolarization, was 110 $\perp 20$ Insec $(n=3)$. The latency increased to $870 \pm 90$ msec after current prepulses of $500 \mathrm{msec}$ duration that hyperpolarized cells to $-100 \mathrm{mV}(n=3$; Fig. $1 B$ ). Prolonging these hyperpolarizing prepulses to $30 \mathrm{sec}$ delayed onset of discharge to $4.1 \pm 0.6 \mathrm{sec}$ ( $\mathrm{n}$ $=3, p<0.05$; Fig. 1C). Increasing the amplitude of the $30 \mathrm{sec}$ hyperpolarization to $-120 \mathrm{mV}$ prolonged the delay to $7.1 \pm 1.1$ $\sec (n=3, p<0.05$; data not shown). When the depolarizing current pulses exceeded threshold values, the delay was strongly reduced (data not shown). Thus, the latency to discharge onset at threshold potentials was dependent both on the amplitude and on the duration of the preceding hyperpolarization. Because maximal delays attributable to $\mathrm{A}$ - and D-currents are expected to be $<1 \mathrm{sec}$ (see below), additional currents appear to be recruited after a 
A
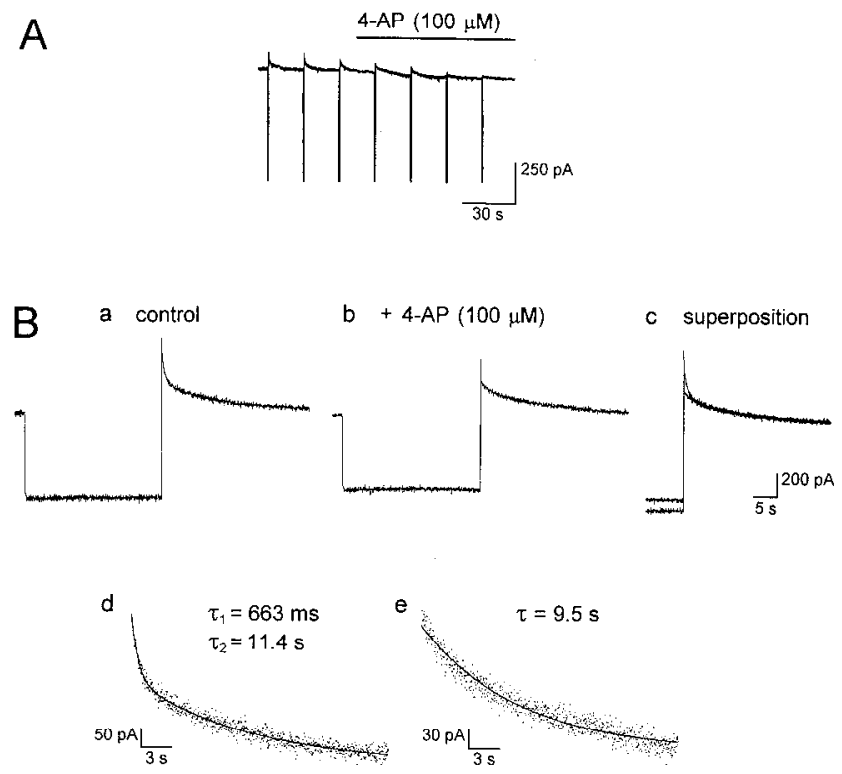

C
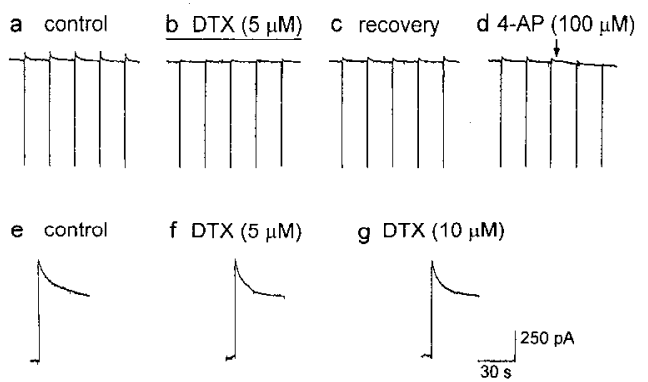

Figure 2. $I_{\mathrm{K} \text { (slow) }}$ can be differentiated from $I_{\mathrm{D}}$ by pharmacological and kinetic criteria. $A$, The cell was held at $-60 \mathrm{mV}$ and stepped to $-120 \mathrm{mV}$ for $500 \mathrm{msec}$ every $20 \mathrm{sec}$. This procedure evoked a small outward current relaxation that was mostly blocked by 4 -AP $(100 \mu \mathrm{M}) . B: a$, When the hyperpolarizing voltage step was prolonged to $30 \mathrm{sec}$, the outward current decayed in a biexponential manner. $b$, Only the faster component $\left(I_{\mathrm{D}}\right)$ was sensitive to $4-\mathrm{AP}$, whereas the slower component $\left(I_{\mathrm{K} \text { (slow) }}\right)$ persisted. $c$, Superposition of the two current relaxations. $d$. Biexponential fitting of the trace in $a$ yielded time constants of $663 \mathrm{msec}$ and $11.4 \mathrm{sec}$, respectively. $e$, Monoexponential fitting of the trace in $b$ yielded a time constant of $9.5 \mathrm{sec}$. $C: a$, This cell was clamped at $-60 \mathrm{mV}$ and stepped to $-120 \mathrm{mV}$ for 500 msec to evoke D-current relaxations. $b$, Twenty seconds after focal application of DTX, the D-current was blocked. $c$, Partial recovery was obtained after $10 \mathrm{~min}$ of washout. $d$, Small relaxations were blocked by application of 4-AP (arrow marks onset of bath application). $e$, In the same cell, a $30 \mathrm{sec}$ hyperpolarizing step evoked $I_{\mathrm{K} \text { (slow) }} f, g, I_{\mathrm{K} \text { (slow) }}$ was insensitive to DTX.

prolonged hyperpolarization. Subsequent experiments to identify such putative currents were performed by using the singleelectrode voltage-clamp technique.

\section{Characterization of hyperpolarization-activated currents}

Voltage-clamp commands were applied that corresponded to the protocols used in the current-clamp recordings described above. Brief voltage commands to -100 or $-120 \mathrm{mV}$ for $500 \mathrm{msec}$ evoked an outward current of $144 \pm 48 \mathrm{pA}(n=14)$ that decayed with a time constant of $754 \pm 65 \mathrm{msec}(n=14)$ and was blocked by $50-100 \mu \mathrm{M} 4-\mathrm{AP}$ (Fig. $2 A$ ). Following the nomenclature of Storm (1988), we refer to this as the "delay" current $\left(I_{\mathrm{D}}\right)$. In some cases, especially with depolarization to above $-60 \mathrm{mV}$, a fast current relaxation persisting in the presence of 50-100 $\mu \mathrm{M} 4-\mathrm{AP}$ (Fig. $2 \mathrm{Bb}$ ) but blocked by $5 \mathrm{~mm} 4$-AP was observed (data not shown). This transient, inactivating with a time constant of $63 \pm$ 9 msec $(n=4)$, likely represents the A-current (Gustafsson et al., 1982; Storm, 1988). Therefore, all current-amplitude measurements were made $120 \mathrm{msec}$ after stepping back to the resting potential, when $I_{\mathrm{A}}$ has inactivated.

In the absence of 4-AP, prolongation of the hyperpolarizing voltage step to $-120 \mathrm{mV}$ by $5-30 \mathrm{sec}$ revealed an additional, slow outward current component after depolarization, leading to a biphasic decay of the total current measured from $120 \mathrm{msec}$ after the voltage step. The faster component decayed with a time constant consistent with inactivation of $I_{\mathrm{D}}$, whereas the remaining component displayed markedly slower decay kinetics $(\tau=11.4$ sec, Fig. $2 B$; averaged data in Fig. $7 B$ ). After application of 4-AP $(100 \mu \mathrm{M})$, the faster component corresponding to $I_{\mathrm{D}}$ was abolished, leaving only the slower component. Because of its long duration and its selectivity for $\mathrm{K}^{+}$ions (see next section), we termed this current $I_{\mathrm{K} \text { (slow) }}$.

Three criteria enabled us to differentiate this slow current from $I_{\mathrm{D}}$. (1) $I_{\mathrm{K} \text { (slow) }}$ is insensitive to 4 -AP at concentrations from 100 $\mu \mathrm{M}$ (Fig. $2 B$ ) to $5 \mathrm{~mm}(p>0.05, n=3$; Fig. $8 A$ ). Hence, all subsequent experiments to characterize the slow current were performed in the continuous presence of $100 \mu \mathrm{M}$ 4-AP to prevent contamination by $I_{\mathrm{D}}$. (2) $I_{\mathrm{K} \text { (slow) }}$ is insensitive to DTX $(5-10 \mu \mathrm{M}$; $107.5 \pm 21.6 \%$ of control, $p>0.05, n=3$ ). DTX blocks the Acurrent (Halliwell et al., 1986) and the D-current ( $n=3$; Fig. 2C) (Wu and Barish, 1992). (3) $I_{\mathrm{K} \text { (slow) }}$ exhibits 10 -fold slower decay kinetics (Figs. 2B, 7A)

'I'he dependence of $I_{\mathrm{K} \text { (slow) }}$ amplitude on both the duration and the magnitude of the hyperpolarizing test pulse could be fitted monoexponentially: the time constant was $9.0 \mathrm{sec}$ for recovery from inactivation ( $n=3$; Fig. $3 A$ ). Similar time constants were obtained with smaller step sizes in the range between -110 and $-70 \mathrm{mV}$. This is consistent with a monoexponential process underlying recovery from inactivation. The voltage for halfactivation lay between -95 and $-100 \mathrm{mV}$ and was independent of the duration of the hyperpolarizing step ( $n=5$; Fig. $3 B$ ).

\section{Ionic nature of the current}

Transient outward currents identified in a variety of neuronal cell types are carried by $\mathrm{K}^{+}$ions (Rudy, 1988; Storm, 1993) or $\mathrm{Cl}^{-}$ ions (Madison et al., 1986). Because $I_{\mathrm{K} \text { (slow) }}$ was ubserved to have similar amplitude when recorded with electrodes filled with $1 \mathrm{M}$ $\mathrm{KMeSO}_{4}$ instead of $2 \mathrm{M} \mathrm{KCl}$, to shift the reversal potential for $\mathrm{Cl}^{-}$ ions in the hyperpolarizing direction (Streit et al., 1989), it was possible to rule out an involvement of a $\mathrm{Cl}^{-}$conductance. The reversal potential for $I_{\mathrm{K} \text { (slow) }}$, obtained by constructing instantaneous current-voltage relationships, was $-93.7 \pm 1.9 \mathrm{mV}(n=3$; Fig. $4 A$ ), which is close to the experimentally determined reversal potential for $\mathrm{K}^{+}$ions (see Fig. $5 A$ ). Furthermore, the reversal potential for the current shifted in a Nernstian manner to -69.6 $\pm 1.0 \mathrm{mV}$ when the external $\mathrm{K}^{+}$concentration was increased from 2.7 to $8.0 \mathrm{~mm}(n=4$; Fig. $4 B)$. The ratio of $\mathrm{K}^{+}$to $\mathrm{Na}^{+}$permeability, calculated from the Goldmann-Hodgkin-Katz equation, was found to be 217 using a value of $119 \mathrm{~mm}$ for the intracellular $\mathrm{K}^{+}$concentration (calculated from the experimentally determined $E_{\mathrm{K}}$ using baclofen iontophoresis; see below). These three results demonstrate that $\mathrm{K}^{+}$ions are the principal charge carriers for $I_{\mathrm{K} \text { (slow) }}$. 


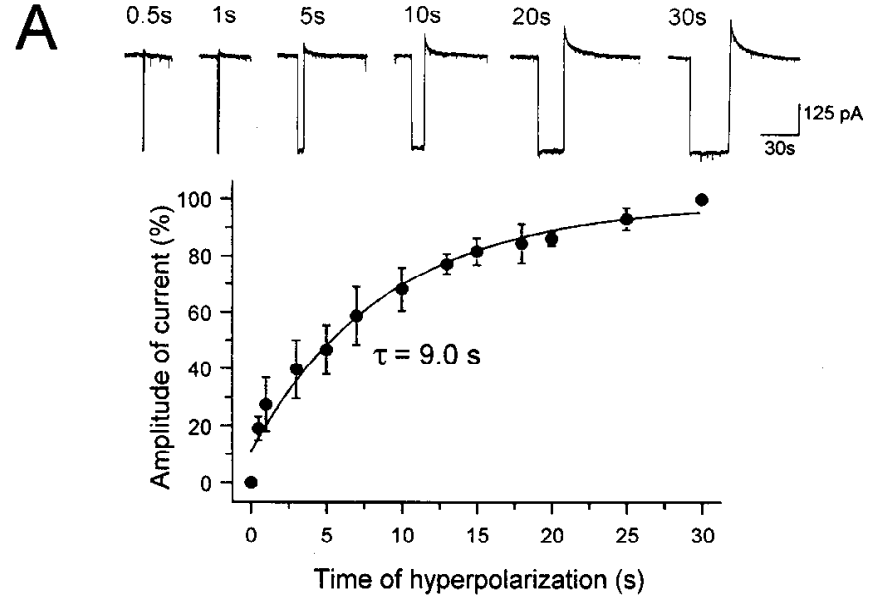

B
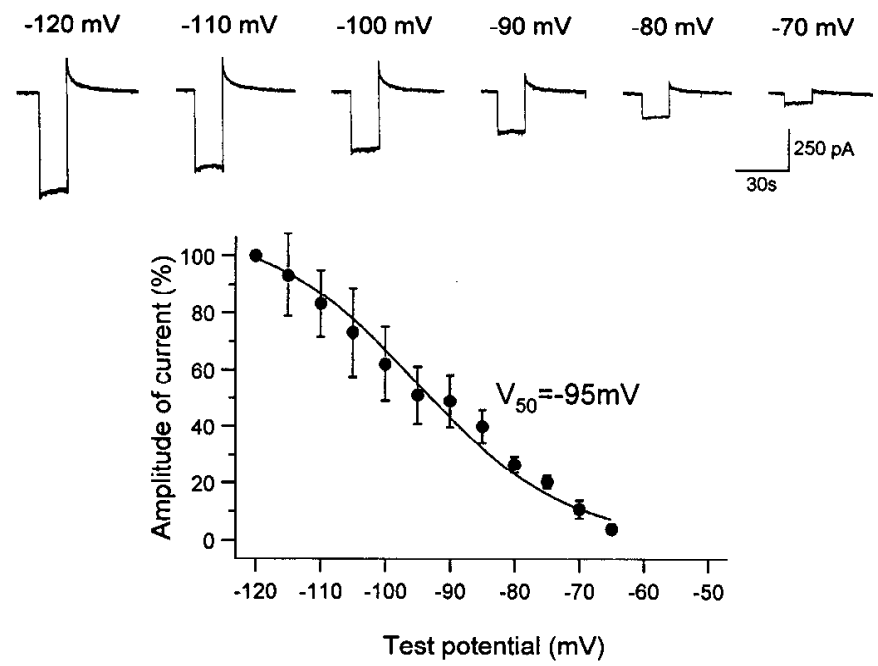

Figure 3. Dependence of $I_{\mathrm{K} \text { (slow) }}$ amplitude on the duration and the amplitude of the hyperpolarizing prepulse. $A$, Representative example of current responses is shown from a cell clamped at $-60 \mathrm{mV}$ and stepped to $-120 \mathrm{mV}$ for various durations (marked at the top of each example). In the graph, averaged data were plotted and normalized to the maximal current amplitude at $30 \mathrm{sec}(n=3)$. Monoexponential fitting revealed a time constant of $9.0 \mathrm{sec}$ for recovery from inactivation. $B$, Similar analysis as in $A$ shows the dependence of $I_{\mathrm{K}(\text { slow) }}$ on the amplitude of the hyperpolarizing step (duration $15 \mathrm{sec}$ ) and gave a voltage for $50 \%$ of recovery from inactivation of $-95 \mathrm{mV}$.

\section{$I_{\mathrm{K} \text { (slow) }}$ is associated with an increase in membrane conductance}

The slow decay kinetics of $I_{\mathrm{K} \text { (slow) }}$ and the long duration of the required hyperpolarizing prepulse raise the possibility that slow ionic transport processes, secondary $\mathrm{K}^{+}$ion shifts, or the activation of an electrogenic ion exchanger pump is responsible for this current. First, changes in the distribution of $\mathrm{K}^{+}$ions attributable to a sustained change in driving force can generate currents after repolarizing the cellular membrane (Noble, 1976). In the present case, however, the reversal potential for $\mathrm{K}^{+}$ions before and after the hyperpolarizing pulse needed to evoke $I_{\mathrm{K} \text { (slow) }}$ remained the same. Iontophoretic application of the $\mathrm{GABA}_{z-}$-receptor agonist baclofen activated an inwardly rectifying $\mathrm{K}^{+}$conductance with a reversal potential of $-99.7 \pm 1.8 \mathrm{mV}(n=4$; Fig. $5 A)$, as reported previously (Newberry and Nicoll, 1984; Gähwiler and Brown, 1985a). When baclofen was applied immediately after a prolonged
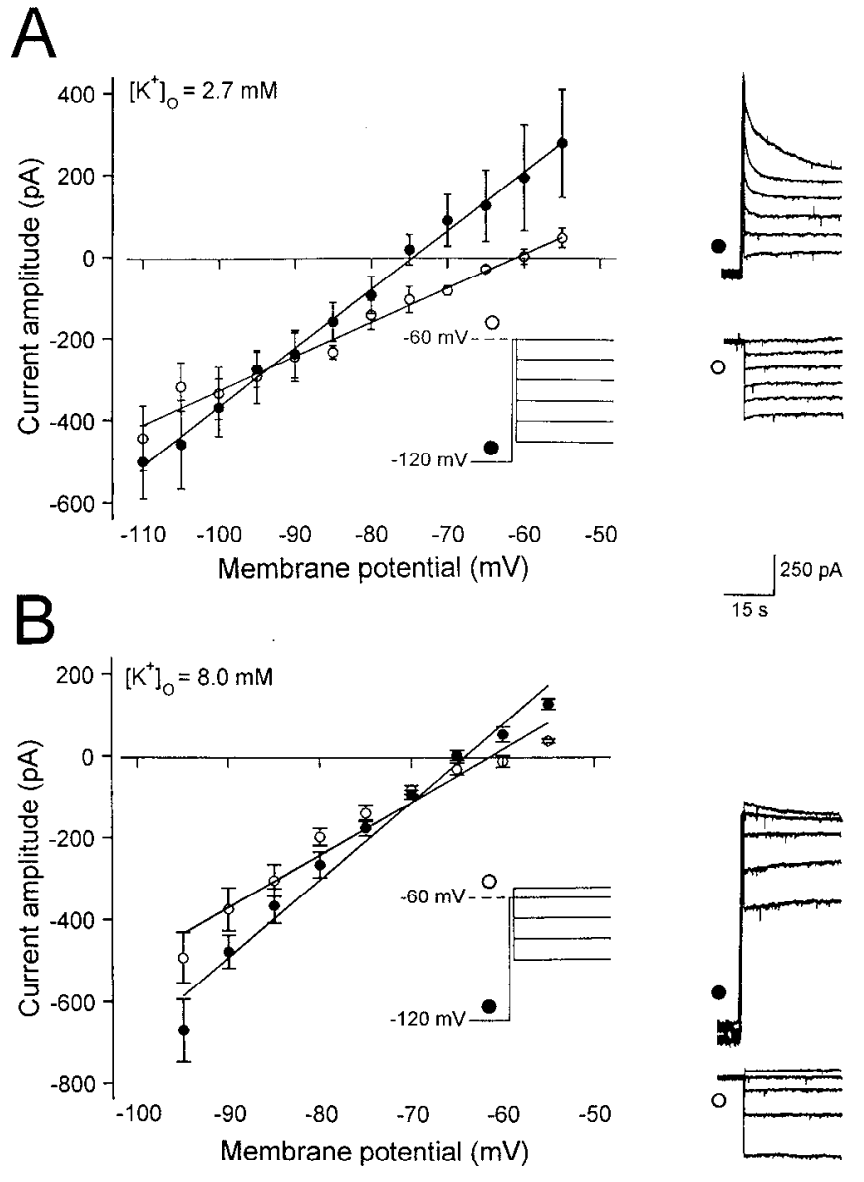

Figure 4. Determination of the reversal potential for $I_{\mathrm{K} \text { (slow). Averaged }}$ data are shown on the left, and representative raw data are shown on the right. Instantaneous current-voltage relationships (insets) with (solid circles) and without (open circles) a hyperpolarizing prepulse were constructed. $A$, The intersection between the two curves, fitted by linear regression (correlation coefficient $r=0.99$ for both curves), yielded the reversal potential for $I_{\mathrm{K} \text { (sluw) }}$ (averaged data $-93.7 \pm 1.7 \mathrm{mV} ; n=3$ ). $B$, The reversal potential was $-69.6 \pm 1.0 \mathrm{mV}(n=4)$ when the extracellular $\mathrm{K}^{+}$concentration was raised to $8.0 \mathrm{mM}$ (correlation coefficient $r=0.99$ for both curves). Under these conditions, voltagc steps to a maximum of -95 $\mathrm{mV}$ were applied. Calibration bars apply to all raw data.

hyperpolarizing prepulse, identical to those used for evoking $I_{\mathrm{K} \text { (slow) }}$, no change in the reversal potential was observed $(-97.7$ $\pm 2.0 \mathrm{mV}, n=4, p>0.05$; Fig. $5 A$ ). Thus, a current relaxation attributable to ionic redistribution can be ruled out.

Second, activation of an electrogenic ion exchanger pump could induce a slow current. All ouabain-sensitive pump current with a time course similar to $I_{\mathrm{K} \text { (slow) }}$ has been described previously in the locus ceruleus (Johnson et al., 1992). Theoretical considerations predict that a current generated by a metabolically driven pump will be associated with negligible changes in input conductance (De Weer, 1984). Therefore, we measured the input conductance of cells by applying $500 \mathrm{msec}$ hyperpolarizing voltage commands of $10 \mathrm{mV}$ at $3 \mathrm{sec}$ intervals during the experimental protocol to elicit $I_{\mathrm{K}(\text { slow) }}$. Figure $5 B$ illustrates a representative trace, demonstrating a significant increase in input conductance $(210+30,2$ of control, $p<0.001 ; n=9$ ) during $I_{\mathrm{K} \text { (slow). Moreover, application }}$ of strophanthidin $(2-7 \mu \mathrm{M})$, an inhibitor of ATPase activity, was without effect ( $p>0.05, n=4$; data not shown). Taken together, these findings exclude the involvement of an electrogenic pump. 


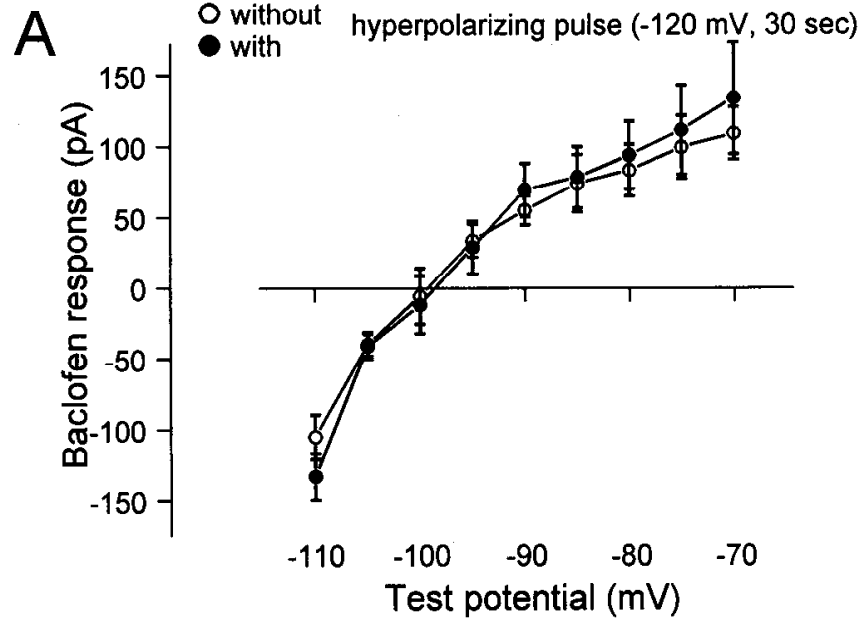

B

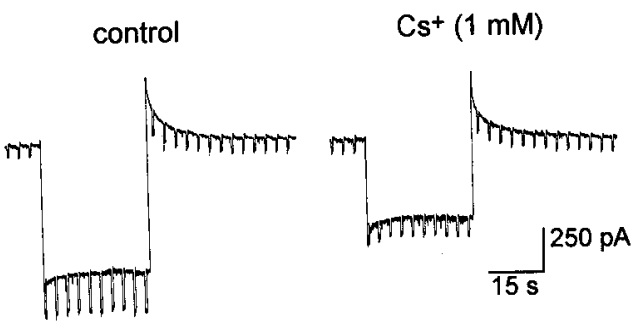

Figure 5. $A, I_{\mathrm{K} \text { (slow) }}$ is not caused by a hyperpolarization-induced shift in $E_{\mathrm{K}}$. Responses to iontophoretically applied baclofen at various potentials were not modified by a hyperpolarizing prepulse. $B, I_{\mathrm{K} \text { (slow) }}$ is associated with an increase in membrane conductance (left). Voltage steps from -60 to $-120 \mathrm{mV}$ were applied for $30 \mathrm{sec}$. Input conductance was measured by applying $10 \mathrm{mV}$ hyperpolarizing pulses of $500 \mathrm{msec}$ every $2 \mathrm{sec}$. The increased conductance during the hyperpolarizing pulse is attributable to inward rectification and was blocked by bath application of $1 \mathrm{mM} \mathrm{Cs}^{+}$ (right).

In summary, we conclude that $I_{\mathrm{K}(\text { slow) }}$ likely is attributable to an increase in $\mathrm{a} \mathrm{K}^{+}$conductance with the following properties: inactivation with a time constant of $7.5 \mathrm{sec}$, and recovery from inactivation after a prolonged period of hyperpolarization.

\section{Voltage dependence of activation and steady-state inactivation}

The voltage dependence for activation and inactivation of $I_{\mathrm{K} \text { (slow) }}$ was characterized by measuring the current elicited at different holding potentials after a $30 \mathrm{sec}$ hyperpolarizing voltage step ( Fig. 6 ). Current amplitudes were normalized to the maximal amplitude and plotted against the membrane potential to which the neuron was stepped during activation of the current. Averaged results from seven cells were fitted by using the Boltzmann equation:

$$
I / I_{\max }=\left[1+\exp \left(-k\left(V-V_{0.5}\right)\right)\right]^{-1},
$$

where $V$ is the membrane potential, $V_{0.5}$ is the membrane potential at which the conductance is half-activated, $I$ is the amplitude of the tail current at the heginning of activation, and $k$ is the slope factor that determines the steepness of the fitted curve. The activation range of the current lay between -90 and $-55 \mathrm{mV}$, with half-activation occurring at $-65.1 \pm 2.6 \mathrm{mV}$ and a slope factor $k=0.20 / \mathrm{mV}$. The maximal conductance $\left(I_{\max }\right)$ was calcu-

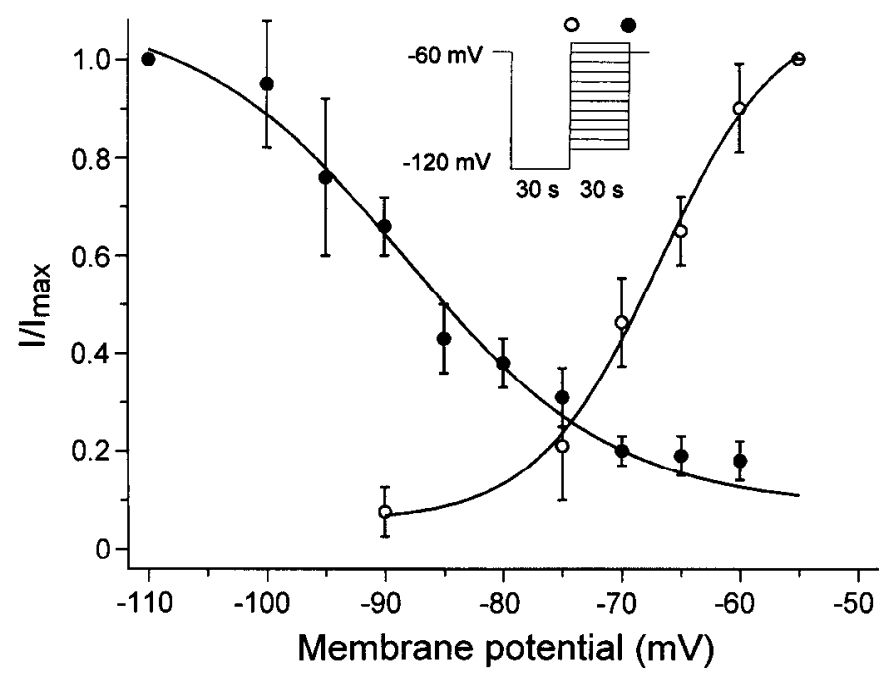

Figure 6. Voltage dependence of activation and inactivation of $I_{\mathrm{K} \text { (slow) }}$. Inset shows the voltage protocol used to obtain current responses for the activation (open circles) and inactivation curves (solid circles). All data were leak-subtracted. Activation was not studied at more depolarized potentials because contaminating currents were activated above $-50 \mathrm{mV}$ that could not be blocked without interfering with $I_{\mathrm{K} \text { (slow) }}$. Boltzmann fitting of the activation curve, therefore, should be considered to be tentative (see Results). The window current for $I_{\text {K(slow) }}$ lay between -85 and $-65 \mathrm{mV}$.

lated to be $7.3 \pm 1 \mathrm{nS}$ at $-55 \mathrm{mV}(n=7)$ and $4.2 \pm 1.5 \mathrm{nS}$ at -75 $\mathrm{mV}(n=4)$.

The voltage dependence of stcady-statc inactivation was determined by clamping the cell to incrementing voltages for $30 \mathrm{sec}$ after the hyperpolarizing pulse. Over this time period, the current decayed completely. The remaining current evoked by stepping back to $-60 \mathrm{mV}$ was measured, and a similar analysis to that for the voltage dependence of activation was performed, yielding values of $V_{0.5}=-84.3 \pm 1.0 \mathrm{mV}$ and $k=-0.12 / \mathrm{mV}(n=7)$.

\section{Kinetics of inactivation}

In the presence of $0.1 \mathrm{~mm} 4-\mathrm{AP}, I_{\mathrm{K} \text { (slow) }}$ was well fitted by a monoexponential function, with an inactivation time constant of $7.5 \pm 0.5 \mathrm{sec}$ at $-60 \mathrm{mV}(n=35$; Fig. $7 A)$. The time constants for all cells ranged between 2 and $15 \mathrm{sec}$ and were distributed in a Gaussian manner around the mean (Fig. $7 B$ ). Thus, $I_{\mathbf{K} \text { (slow) }}$ inactivated 3 - to 10 -fold slower than $I_{\mathrm{N}}$. The time constant of inactivation decreased with hyperpolarization, as determined from the instantaneous current-voltage relationships (Fig. 7C). These data, however, are influenced by the kinetics of $I_{\mathrm{K} \text { (slow) }}$ deactivation, which cannot be isolated from inactivation because there is no situation in which $I_{\mathrm{K} \text { (slow) }}$ does not inactivate. The fitting of $I_{\mathrm{K} \text { (slow) }}$ was not improved by using a multiexponential function, indicating that this current reflects the decay of a single conductance.

\section{$\mathrm{K}^{+}$-channel blockers}

We determined the sensitivity of $I_{\mathrm{K} \text { (slow) }}$ to a variety of $\mathrm{K}^{+}$. channel blockers (Fig. 8B). Hyperpolarization-activated, inwardly rectifying currents in various cell types are reduced by low concentrations (1-2 mM) of extracellular $\mathrm{Cs}^{+}$(Halliwell and Adams, 1982; Mayer and Westbrook, 1983; McCormick and Pape, 1990). In CA3 neurons, extracellular application of $\mathrm{Cs}^{+}(1 \mathrm{~mm})$ reduced the amplitude of $I_{\mathrm{K} \text { (slow) }}$ by $19.6 \pm 4.5 \%(p<0.005 ; n=8)$ without changing the time constant of inactivation $(91.9 \pm 7.4 \%$ 

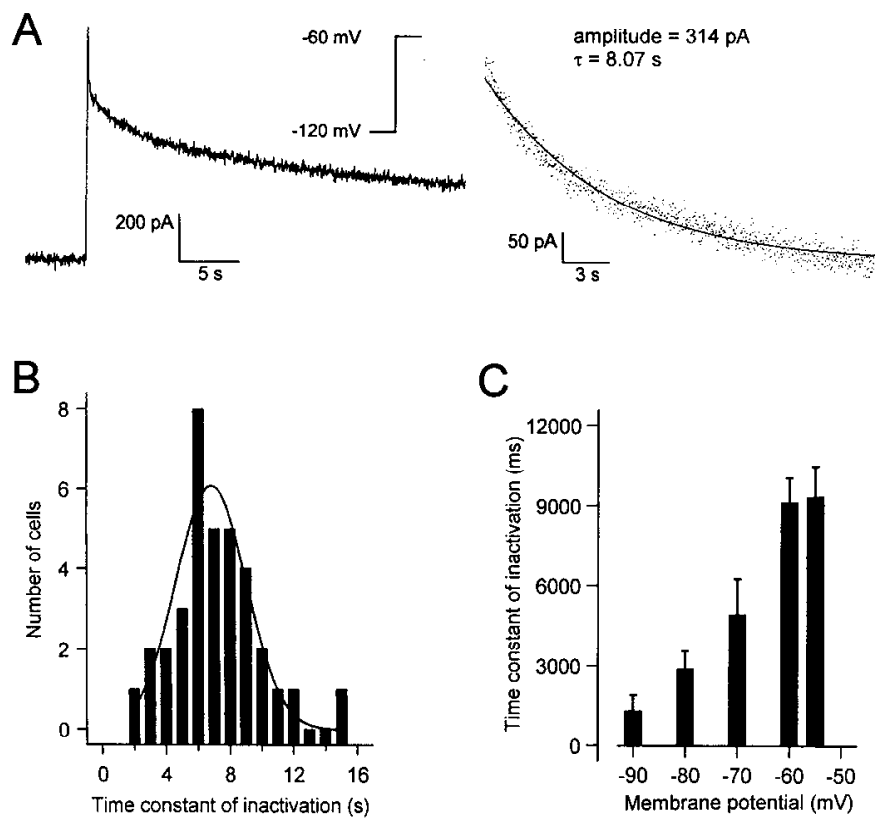

Figure 7. Kinetic analysis of $I_{\mathrm{K}(\text { slow) }}$. A, Representative current relaxation (left) and a monoexponential fit (right) with an amplitude of $314 \mathrm{pA}$ and an inactivation time constant of $8.07 \mathrm{sec}$ are shown. $B$, Gaussian fitting of the distribution of time constants gave an average of $7.5 \pm 0.5 \mathrm{sec} . C$, Voltage dcpendence of inactivation of $I_{\mathrm{K}(\text { slow })}(n=4)$. Decay time constants were not analyzed above $-55 \mathrm{mV}$ because other currents activated at depolarized potentials contaminated any further analysis.

of control, $p>0.05 ; n=8$ ). In cells intracellularly perfused with $\mathrm{Cs}^{+}, I_{\mathrm{K} \text { (slow) }}$ could not be evoked ( $n=5$; data not shown).

Slow transient $\mathrm{K}^{+}$currents in the hippocampus are differentially sensitive to TEA (Segal and Barker, 1984; Numann et al., 1987; Ficker and Heinemann, 1992). In the case of $I_{\text {K(slow) }}$, we obtained a maximal suppression of $56.7 \pm 7.4 \%(p<0.01 ; n=8)$ by using very high concentrations of TEA $(50 \mathrm{~mm})$. TEA at a concentration of $10 \mathrm{~mm}$ suppressed $I_{\mathrm{K} \text { (slow) }}$ by $20.9 \pm 9.9 \%(p<$ $0.05 ; n=6)$. Extracellular application of $\mathrm{Ba}^{2+}(1 \mathrm{mM})$ reduced the amplitude of $I_{\text {K(slow) }}$ by $37.6 \pm 7.3 \%(p<0.05 ; n=7)$. As mentioned above, DTX $(5-10 \mu \mathrm{M}$; Fig. $2 B)$ blocked $I_{\mathrm{D}}$ but not $I_{\mathrm{K} \text { (slow) }}(107.5 \pm 21.6 \%$ of control, $\rho>0.05)$. Focal application of CTX $(0.5-2.5 \mu \mathrm{M})$, known to block $\mathrm{Ca}^{2+}$-activated $\mathrm{K}^{+}$conductances (Miller et al., 1985), had no effect on $I_{\mathrm{K} \text { (slow) }}(93.7 \pm 3.9 \%$ of control, $p>0.05 ; n=8$ ), but it did prolong the decay time of the action potential ( $p<0.05 ; n=3$ ), as shown previously (Storm, 1987). Another class of substances, the sulfonylureas, blocks ATPdependent $\mathrm{K}^{+}$conductances (Rorsman and Trube, 1990). Glibenclamide, a member of this class, had no effect on $I_{\mathrm{K} \text { (slow) }}(99.7$ $\pm 11.1 \%$ of control, $p>0.05 ; n=7$ ).

One would expect that the large voltage steps required to elicit $I_{\mathrm{K} \text { (slow) }}$ activate voltage-gated $\mathrm{Ca}^{2+}$ currents and, in turn, $\mathrm{Ca}^{2+}$ dependent conductances (Brown et al., 1990). $I_{\mathrm{K} \text { (slow) }}$ howcver, was not modified by changes in intracellular $\mathrm{Ca}^{2+}$ levels. The current was not affected by preventing $\mathrm{Ca}^{2+}$ influx with extracellular application of $\mathrm{Cd}^{2+}(50 \mu \mathrm{M}, 100.4 \pm 35.6 \%$ of control, $p>$ $0.05 ; n=8)$ or low extracellular $\mathrm{Ca}^{2+}$ concentrations $(0.5 \mathrm{~mm}$ $\mathrm{Ca}^{2+}, 10 \mathrm{~mm} \mathrm{Mg}{ }^{2+}, 93.8 \pm 8.1 \%$ of control, $p>0.05, n=11$; data not shown). In recordings from cells intracellularly perfused with BAPTA ( $25 \mathrm{mM}), I_{\mathrm{K} \text { (slow) }}$ was not altered ( $n=4$; data not shown), ruling out a dependence on a change in intracellular $\mathrm{Ca}^{2+}$.
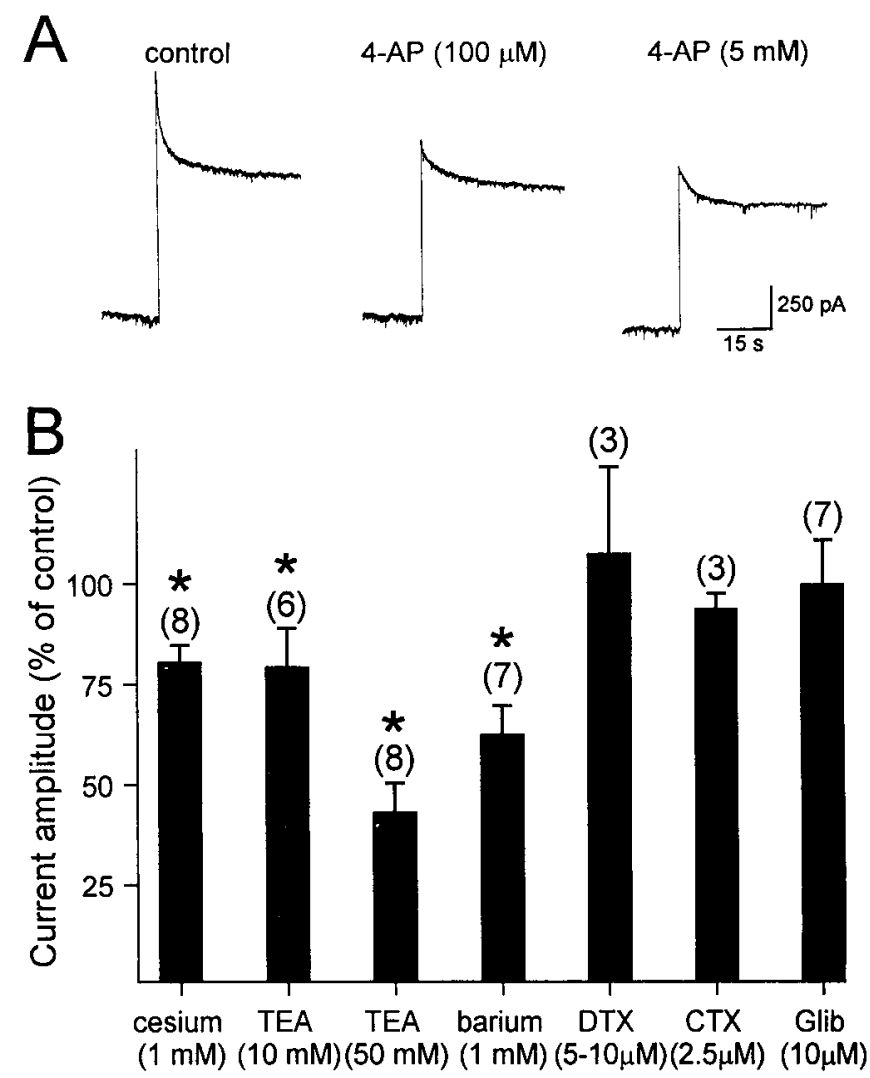

Figure 8. Effects of $\mathrm{K}^{+}$-channel blockers on $I_{\mathrm{K} \text { (slow) }} A$, 4-AP does not suppress $I_{\mathrm{K} \text { (slow) }}$. Left, Currents evoked after a 30 sec hyperpolarizing step to $-120 \mathrm{mV}$ for $30 \mathrm{sec}$. Middle, The faster current component was blocked after application of $100 \mu \mathrm{M} 4$-AP. Right, Raising the concentration of 4-AP to $5 \mathrm{~mm}$ still had no effect on $I_{\mathrm{K}(\mathrm{slow})} . B$, Histogram summarizing the effects of $\mathrm{K}^{+}$-channel blockers on $I_{\mathrm{K} \text { (slow). Asterisk denotes significant difference }}$ from control; Glib, glibenclamide.

\section{Metabotropic agonists}

$I_{\mathrm{K} \text { (slow) }}$ was reduced by application of $1 S, 3 R$-ACPD $(100 \mu \mathrm{M})$, a specific agonist for metabotropic glutamate receptors, and by MCh $(5 \mu \mathrm{M})$ or muscarine $(10 \mu \mathrm{M})$, agonists at muscarinic cholinergic receptors (Fig. $9 A$ ). It should be noted that these agonists did not alter significantly the peak amplitude of the current (271 \pm 34 vs $266 \pm 37 \mathrm{pA}$ for $1 S, 3 R-\mathrm{ACPD}$ at $100 \mu \mathrm{M}, n=15 ; 163 \pm$ 38 vs $205 \pm 27 \mathrm{pA}$ for $\mathrm{MCh}$ at $5 \mu \mathrm{M}, p>0.05, n=3$ ). Rather, they induced an apparent, concentration-dependent increase in the rate of decay of $I_{\mathrm{K} \text { (slow) }}$, as assessed by monoexponential fitting (Fig. 9B). Compared with the effects on previously studied $\mathrm{K}^{+}$ currents, higher concentrations of these metabotropic agonists were required for suppression (Gerber and Gähwiler, 1994). The actions of $\mathrm{MCh}$ were antagonized fully by $1 \mu \mathrm{M}$ atropine. Metabotropic agonists did not block $I_{\mathrm{D}}$ or change its time course (741 \pm $45 \mathrm{vs} 729 \pm 32 \mathrm{msec}$ for $1 S, 3 R-\mathrm{ACPD}$ at $100 \mu \mathrm{M}, n=3 ; 675 \pm 96$ vs $673 \pm 42 \mathrm{msec}$ for $\mathrm{MCh}$ at $5 \mu \mathrm{M}, n=6$; Fig. $9 C$ ).

The apparent suppression of $I_{\text {K(slow) }}$ after stimulation of metabotropic receptors could arise either via a direct inhibition of the underlying conductance or via activation of an inward current that superimposes on $I_{\mathrm{K} \text { (slow). }}$. To address this question, experiments were designed to examine the action of agonists at restricted time points during $I_{\mathrm{K} \text { (slow) }}$ activation using the iontophoretic technique of drug application (Fig. 10). If $I_{\mathrm{K} \text { (slow) }}$ is suppressed by activation of metabotropic receptors, the pharmacological response should be greater at the peak amplitude of 


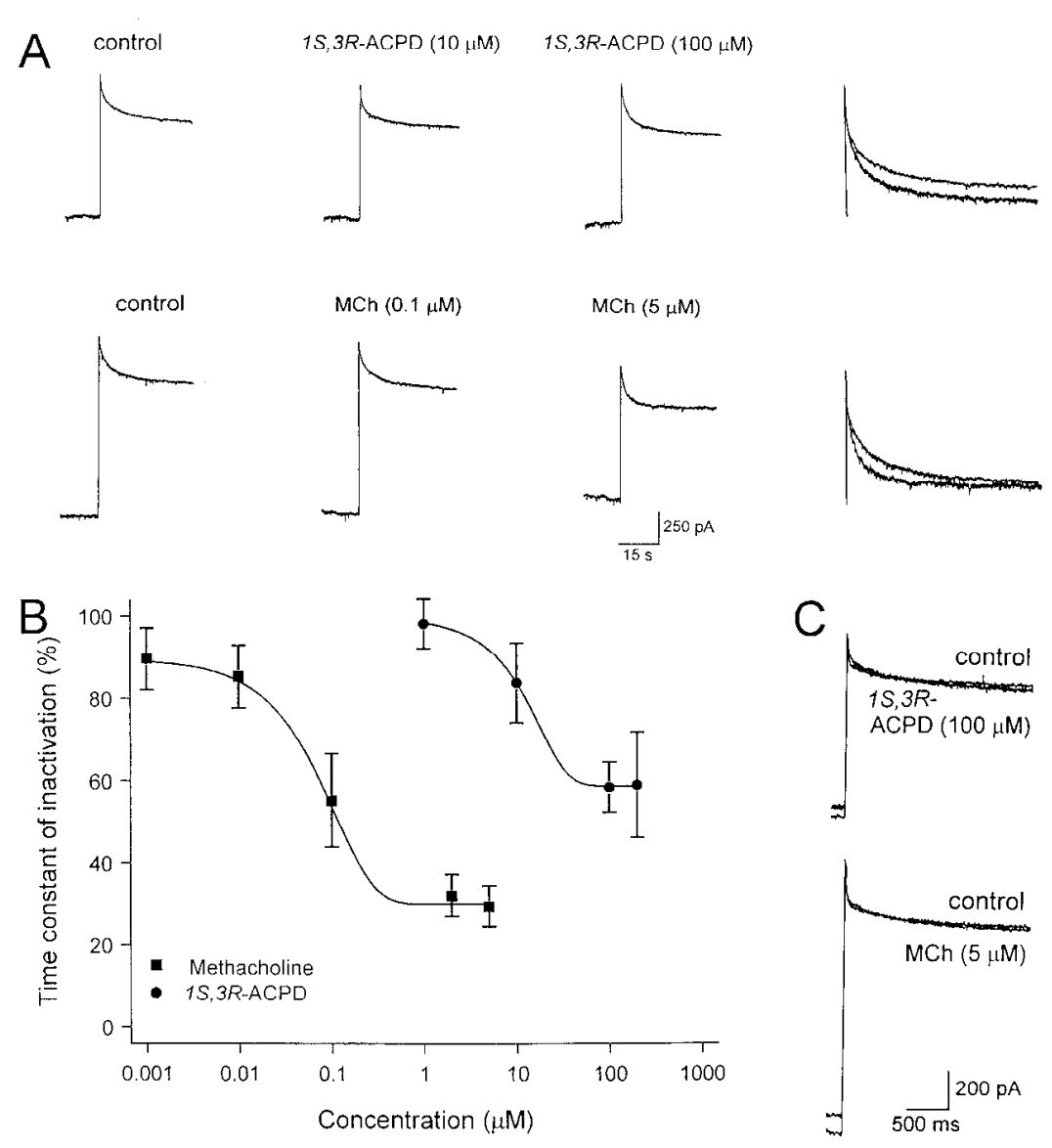

Figure 9. Reduction of $I_{\mathrm{K} \text { (slow) }}$ by metabotropic glutamatergic and cholinergic agonists. $A$, Effects of $1 S, 3 R$-ACPD (top) and MCh (bottom) are shown at two different concentrations. Cells were clamped at $-120 \mathrm{mV}$ for $30 \mathrm{sec}$ and then stepped back to $-60 \mathrm{mV}$. Control and test responses at maximal agonist concentration are shown superimposed and enlarged by a factor of two on the right, aligned at their peak amplitudes. Responses to agonists were characterized by measuring the initial amplitude and the apparent decrease in inactivation time constant of $I_{\mathrm{K} \text { (slow) }} . B$, Responses were concentration-dependent, with an $\mathrm{IC}_{50}$ for $I S, 3 R$-ACPD of $13 \mu \mathrm{M}$ and an $\mathrm{IC}_{50}$ for $\mathrm{MCh}$ of $0.06 \mu \mathrm{M}$. Each concentration was tested 3-15 times. $C$, Metabotropic agonists at their maximal concentrations for $I_{\mathrm{K} \text { (slow) }}$ suppression had no cffect on inactivation of $I_{\mathrm{D}}$, evoked at $-60 \mathrm{mV}$ after a $500 \mathrm{msec}$ hyperpolarizing step from -60 to $-120 \mathrm{mV}$.
$I_{\mathrm{K} \text { (slow) }}$. Indeed, the amplitude of the response to agonists when applied during $I_{\mathrm{K} \text { (slow) }}$ was significantly greater than in control (1S,3R-ACPD: $179 \pm 48$ vs $108 \pm 34$ pA, $p<0.05, n=3$; MCh: $228 \pm 25$ vs $124 \pm 13$ pA, $p<0.001, n=6$; Fig. $10 A, B)$. On the other hand, iontophoretic application of AMPA caused current responses that remained unchanged in amplitude in the presence of $I_{\mathrm{K} \text { (slow) }}(293 \pm 36$ vs $292 \pm 36$ pA, $p>0.05, n=4$; Fig. 10C). Thus, these experiments suggest that $I_{\mathrm{K} \text { (slow) }}$ can be modulated by activation of metabotropic receptors.

\section{DISCUSSION}

A slow, voltage-dependent $\mathrm{K}^{+}$current is evoked when the membrane potential is stepped back to resting potential after a period of prolonged membrane hyperpolarization in hippocampal CA3 pyramidal cells. The purpose of this study was to characterize this current, to classify it within the family of known hippocampal $\mathrm{K}^{+}$ currents, and to describe the physiological context in which it may be of importance. To reflect the slow kinetics of this current, we propose that it be named $I_{\mathrm{K} \text { (slow). }}$.

Prolonged hyperpolarization (tens of seconds) preceding a depolarizing stimulus induces a delay in onset of action-potential generation consistent with the activation of $I_{\mathrm{K} \text { (slow) }}$. A maximal delay in depolarization-induced discharge of 4-5 sec is observed after a $30 \mathrm{sec}$ hypcrpolarizing period at $-100 \mathrm{mV}$, which corresponds to the voltage protocol needed to activate $I_{\mathrm{K} \text { (slow) }}$ strongly. The duration of the delay lies in the same range as the time required for $I_{\mathrm{K} \text { (slow) }}$ inactivation. In contrast, hyperpolarizing commands with a duration of $0.5-1 \mathrm{sec}$ cause a much briefer delay to the first action potential. Although these observations strongly suggest that $I_{\mathrm{K} \text { (slow) }}$ contributes to the control of discharge onset, specific blockers of the ionic channel underlying $I_{\mathrm{K} \text { (slow) }}$ will be required to prove this hypothesis definitively.

For the voltage-clamp characterization, prepulses to $-120 \mathrm{mV}$ were used to activate $I_{\mathrm{K} \text { (slow) }}$ maximally, because this facilitated analysis. Under partially disinhibited conditions leading to epileptiform activity, inhibitory synaptic potentials can be evoked with a peak amplitude up to $30 \mathrm{mV}$ below resting potential and a duration of $2 \mathrm{sec}$ (Scanziani et al., 1991). Thus, it is likely that under these physiological conditions $I_{\mathrm{K} \text { (slow) }}$ can be activated at least partially (Figs. 3, 6).

Compared with previously described hippocampal ionic currents, the slow current presented in this study exhibits unique kinetic features. $I_{\mathrm{K} \text { (slow) }}$ decays with a slower time course than previously identified transient $\mathbf{K}^{+}$currents (Storm, 1986; Ficker and Heinemann, 1992; Wu and Barish, 1992) and requires a much longer hyperpolarizing conditioning pulse to recover from inactivation. In one study, however, complete recovery from inactivation of $I_{\mathrm{D}}$ was observed after only $5 \mathrm{sec}$ (Storm, 1988). This may reflect a contribution of a current corresponding to $I_{\mathrm{K} \text { (slow) }}$ (Storm, 1986).

The slow kinctics prompted us to consider ionic mechanisms other than a conductance change that could be evoked by prolonged hyperpolarization. The experimental data, however, argue against a current attributable to ionic redistribution or electrogenic pump activity. Thus, the properties of $I_{\mathrm{K} \text { (slow) }}$ are consistent with activation of a slow transient voltage-dependent $\mathrm{K}^{+}$conductance. Ion channels with kinetics that could generate a macroscopic current similar to $I_{\mathrm{K} \text { (slow) }}$ have been cloned and characterized. The Shaker-channel variant $\mathrm{ShB}$ from Drosophila displays 

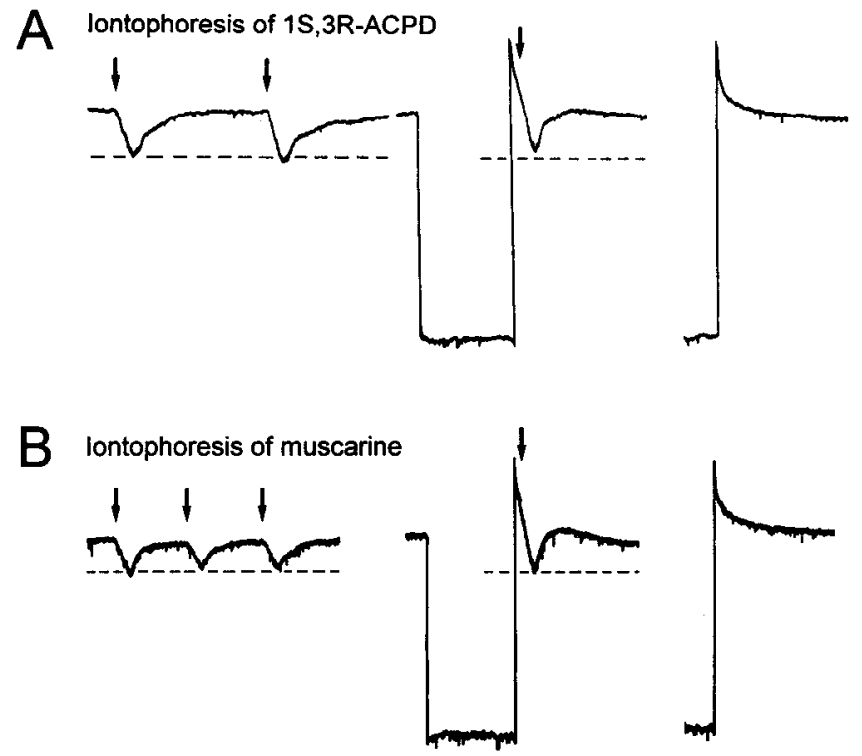

C Iontophoresis of AMPA

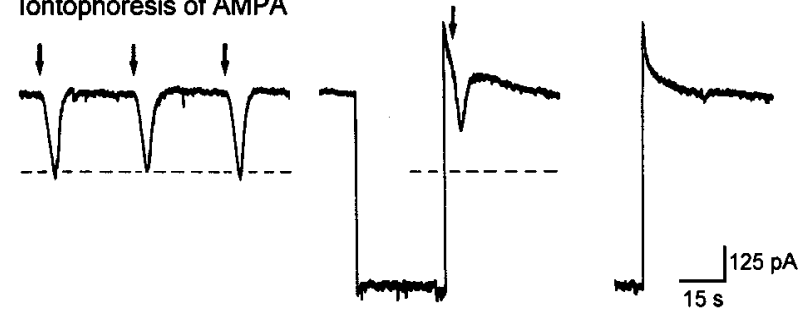

Figure 10. Responses to metabotropic agonists are enhanced when applied during $I_{\mathrm{K}(\mathrm{slow})}$. A, Iontophoretic application of $1 S, 3 R$-ACPD under control conditions induced small inward currents (arrows) caused by suppression of $\mathbf{K}^{+}$conductance (left). When the same metabotropic response was evoked during $I_{\mathrm{K} \text { (slow) }}$ (middle), the response was greater, suggesting that an additional current, namely $I_{\mathrm{K} \text { (slow), }}$, is blocked. $I_{\mathrm{K} \text { (slow) }}$ during control is displayed for comparison on the right. $B$, Similar enhancement was observed when muscarine was applied iontophoretically. $C$, In contrast, responses to AMPA, an ionotropic agonist, were not increased during $I_{\mathrm{K}(\text { slow) }}$. Dashed lines indicate peak of iontophoretic responses in control.

inactivation kinetics in the range of seconds (Hoshi et al., 1991), giving rise to a slowly inactivating current. Heteromultimeric $\mathrm{K}^{+}$ channels composed of two different RCK proteins (RCK1 and RCK4, corresponding to $K_{\mathrm{v}} 1.1$ and 1.4; for review, see Pongs, 1992) expressed in IIeLa cells cause rapidly activating ( $-10 \mathrm{mscc})$ and slowly inactivating $(\sim 1 \mathrm{sec})$ currents that require a time period of 5-6 sec for $50 \%$ recovery from inactivation (Ruppersberg et al., 1990). Thus, structural substrates for channels causing prolonged $\mathrm{K}^{+}$currents have been identified, and these substrates may share similarities with the channel underlying $I_{\mathrm{K} \text { (slow) }}$.

A number of transient $\mathrm{K}^{+}$currents have been characterized in hippocampal neurons (Segal and Barker, 1984; Numann et al., 1987; Ficker and Heinemann, 1992). A current activating in $<100$ msec and decaying biexponentially with time constants of 500 msec and $3.4 \mathrm{sec}$ has been identified in cultured pyramidal cells (Ficker and Heinemann, 1992), thus suggesting similarities to $I_{\mathrm{D}}$ and $I_{\mathrm{K} \text { (slow) }}$. 4-AP, however, suppressed the fast and slow components of this current to the same extent, and the current was mostly blocked with $20 \mathrm{~mm}$ TEA. The activation-inactivation properties of the slow current component revealed a window current around $-30 \mathrm{mV}$, whereas the window current of $I_{\mathrm{K} \text { (slow) }}$ is close to resting potential. An additional 4-AP-resistant, slowly inactivating current (time constant of $\sim 10 \mathrm{sec}$ ) with similar voltage dependence to $I_{\mathrm{K} \text { (slow) }}$ has been described in CA1 pyramidal cells, but further characterization will be required to identify it as $I_{\mathrm{K} \text { (slow) }}$ (Storm, 1986). These results taken together suggest that $I_{\mathrm{K} \text { (slow) }}$ is a novel member of the class of transient $\mathrm{K}^{+}$currents. Alternatively, $I_{\mathrm{K} \text { (slow) }}$ may represent a deactivating tail current of a rapidly activating, $\mathrm{K}^{+}$-selective inward rectifier. The fact that $\mathrm{Cs}^{+}$blocks $I_{\mathrm{K} \text { (slow) }}$ only weakly does not rule out this possibility, because the blockade of inward-rectifier currents by $\mathrm{Cs}^{+}$is voltage-dependent, being relieved after depolarization (Hagiwara et al., 1976). On the other hand, the linear instantaneous currentvoltage relationship exhibited by $I_{\mathrm{K} \text { (slow) }}$ at both 2.7 and $8.0 \mathrm{~mm}$ extracellular $\mathrm{K}^{+}$concentration argues against an inwardly rectifying current (Fig. 4).

Metabotropic glutamatergic (and cholinergic) receptor activation leads to a long-lasting increase in cellular excitability via G-protein-mediated suppression of numerous $\mathrm{K}^{+}$conductances (Gerber and Gähwiler, 1994). In the present study, we found that stimulating these receptors with high concentrations of agonists decreased the apparent decay time constant of $I_{\mathrm{K} \text { (slow) }}$. Because activation of metabotropic receptors improves the space-clamp because of the reduction of leak conductances, this effect may be attributable merely to changes in the electrotonic properties of the neurons. Three observations, however, argue against such an interpretation: (1) both the amplitude and time constant of another transient $\mathrm{K}^{+}$current, $I_{\mathrm{D}}$, were unchanged after activation of metabotropic receptors; (2) a reduction in passive membrane conductance in the presence of extracellular $\mathrm{Cs}^{+}$had no effect on $I_{\mathrm{K} \text { (slow) }}$ decay kinetics; and (3) results from iontophoretic application of metabotropic agonists show an increase in the magnitude of the iontophoretic response. 'I'hus, the reduction of this current is not an indirect effect; rather, it reflects a coupling between metabotropic receptors and the conductance underlying $I_{\mathrm{K} \text { (slow) }}$. A change in the kinetics, but not in the initial amplitude, of a current after receptor activation could reflect a voltage dependence in the signal-transduction mechanism (Bean, 1989). Because $I_{\mathrm{K} \text { (slow) }}$ can be evoked only within a limited voltage range, this hypothesis could not be tested satisfactorily.

In conclusion, the modulation of $I_{\mathrm{K} \text { (slow) }}$ by metabotropic glutamatergic and cholinergic receptors represents an additional mechanism by which these receptors can control neuronal function. Voltage-dependent $\mathrm{K}^{+}$currents, such as $I_{\mathrm{AHP}}$ and $I_{\mathrm{M}}$, that are known to be inhibited after activation of metabotropic receptors typically are evoked by depolarizing steps well above resting potential. In contrast, $I_{\mathrm{K} \text { (slow) }}$ activates at potentials close to rest and displays a window current around $-75 \mathrm{mV}$, that is, far below

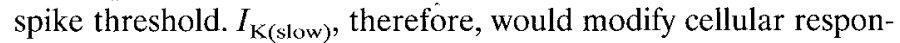
siveness to depolarizing input as a function of the prevailing membrane potential. The observation that metabotropic glutamatergic and cholinergic receptors can be activated with synaptic stimulation (Gähwiler and Brown, 1985b; Gerber ct al., 1993) suggests that modulation of $I_{\mathrm{K} \text { (slow) }}$ by neurotransmitter receptors contributes to synaptic processing.

\section{REFERENCES}

Bean BP (1989) Neurotransmitter inhibition of neuronal calcium currents by changes in channel voltage dependence. Nature 340:153-156. Brown DA, Gähwiler BH, Griffith WH, Halliwell JV (1990) Membrane currents in hippocampal neurons. Prog Brain Res 83:141-160. 
Byrne JH, Shapiro E, Dieringer N, Koester J (1979) Biophysical mechanisms contributing to inking behavior in Aplysia. J Neurophysiol 42:1233-1250

Dekin MS, Gelling PA, Julınson SM (1987) In vilro characterization of neurons in the ventral part of the nucleus tractus solitarius. I. Identification of neuronal types and repetitive firing properties. $J$ Neurophysiol 58:195-214.

De Weer P (1984) Electrogenic pumps: theoretical and practical considerations. In: Electrogenic transport: fundamental principles and physiological implications, Vol 38, Society of General Physiologists series (Blaustein MP, Lieberman M, eds), pp 1-15. New York: Raven.

Ficker E, Heinemann U (1992) Slow and fast transient potassium currents in cultured rat hippocampal cells. J Physiol (Lond) 445:431-455.

Gähwiler BH (1981) Organotypic monolayer cultures of nervous tissue. J Neurosci Methods 4:329-342.

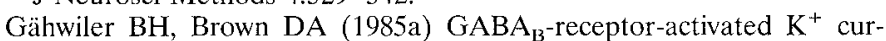
rent in voltage-clamped $\mathrm{CA} 3$ pyramidal cells in hippocampal cultures. Proc Nall Acad Sci USA 82:1558-1562.

Gähwiler BH, Brown DA (1985b) Functional innervation of cultured hippocampal neurones by cholinergic afferents from co-cultured septal explants. Nature 313:57\%-579.

Gerber U, Gähwiler BH (1994) Modulation of ionic currents by metabotropic glutamate receptors in the CNS. In: The metabotropic glutamate receptors (Conn PJ, Patel J, eds), pp 125-146. Totawa, NJ: Humana.

Gerber U, Lüthi A, Gähwiler BH (1993) Inhibition of a slow synaptic response by a metabotropic glutamate receptor antagonist in hippocampal CA3 pyramidal cells. Proc R Soc Lond [Biol] 254:169-172.

Getting PA (1983) Mechanisms of pattern generation underlying swimming in Tritonia. III. Intrinsic and synaptic mechanisms for delayed excitation. J Neurophysiol 49:1036-1050.

Gustafsson B, Galvan M, Grafe P, Wigström H (1982) A transient outward current in a mammalian central neurone blocked by 4-aminopyridine. Nature 299:252-254.

Hagiwara S, Miyazaki S, Rosenthal NP (1976) Potassium current and the effect of cesium on this current during anomalous rectification of the egg cell membrane of a starfish. J Gen Physiol 67:621-638.

Halliwell JV, Adams PR (1982) Voltage-clamp analysis of muscarinic excitation in hippocampal neurons. Brain Res 250:71-92.

Halliwell JV, Othman IB, Pelchen-Matthews A, Dolly JO (1986) Central action of dendrotoxin: selective reduction of a transient $\mathrm{K}$ conductance in hippocampus and binding to localized acceptors. Proc Natl Acad Sci USA 83:493-497.

Hille B (1992) Ionic channels of excitable membranes. Sunderland, MA: Sinauer.

Hoshi T, Zagotta WN, Aldrich RW (1991) Two types of inactivation in Shaker $\mathrm{K}^{+}$cliannels: effects of alterations in the carboxy-terminal region. Neuron 7:547-556.

Johnson SW, Seutin V, North RA (1992) Burst firing in dopamine neurons induced by $N$-methyl-D-aspartate: role of electrogenic sodium pump. Science 258:665-667.

Lüthi A, Gähwiler BH, Thompson SM, Gerber U (1994) A slow potassium current evoked after a hyperpolarizing pre-pulse is reduced by metabotropic glutamate receptor activation in rat hippocampus. Soc Neurosci Abstr 305:18.

Madison DV, Malenka RC, Nicoll RA (1986) Phorbol esters block a voltage-sensitive chloride current in hippocampal pyramidal cells. $\mathrm{Na}$ ture 321:695-697.
Mayer ML, Westbrook GL (1983) A voltage-clamp analysis of inward (anomalous) rectification in mouse spinal sensory ganglion neurones. J Physiol (Lond) 340:19-45.

McComick DA (1991) Funclional properties of a slowly inactivating potassium current in guinea pig dorsal lateral geniculate relay neurons. J Neurophysiol 66:1176-1189.

McCormick DA, Pape HC (1990) Properties of a hyperpolarizationactivated cation current and its role in rhythmic oscillation in thalamic relay neurones. J Physiol (Lond) 431:291-318.

Miller C, Moczydlowski E, Latorre R, Phillips M (1985) Charybdotoxin, a high-affinity inhibitor of single $\mathrm{Ca}^{2+}$-activated $\mathrm{K}^{+}$channels of mammalian skeletal muscle. Nature 313:316 318 .

Newberry NR, Nicoll RA (1984) Direct hyperpolarizing action of baclofen on hippocampal pyramidal cells. Nature 308:450-452.

Nisenbaum ES, Xu ZC, Wilson CJ (1994) Contribution of a slowly inactivating potassium current to the transition to firing of neostriatal spiny projection neurons. J Neurophysiol 71:1174-1189.

Noble SJ (1976) Potassium accumulation and depletion in frog atrial muscle. J Physiol (Lond) 258:579-613.

Numann RE, Wadman WJ, Wong RKS (1987) Outward currents of single hippocampal cells obtained from the adult guinea-pig. J Physiol (Lond) 393:331-353.

Pongs O (1992) Molecular biology of voltage-dependent potassium channels. Physiol Rev 72:S69-S88.

Rorsman P, Trube G (1990) Biophysics and physiology of ATP-regulated $\mathrm{K}^{+}$chamels (KATP). In: Poldssium channels. Structure, classification, function and therapeutic potential (Cook NS, ed), pp 96-116. Chichester: Ellis Horwood.

Rudy B (1988) Diversity and ubiquity of K channels. Neuroscience $25: 729-749$.

Ruppersberg JP, Schröter KH, Sakmann B, Stocker M, Sewing S, Pongs O (1990) Heteromultimeric channels formed by rat brain potassiumchannel proteins. Nature 345:535-537.

Scanziani M, Gähwiler BH, Thompson SM (1991) Paroxysmal inhibitory potentials mediated by $\mathrm{GABA}_{\mathrm{B}}$ receptors in partially disinhibited rat hippocampal slice cultures. J Physiol (Lond) 444:375-396.

Segal M, Barker JL (1984) Rat hippocampal neurons in culture: potassium conductances. J Neurophysiol 51:1409-1433.

Storm JF (1986) A-Current and Ca-dependent transient outward current control the initial repetitive firing in hippocampal neurons (Abstr). Biophys J 49:369A.

Storm JF (1987) Action potential repolarization and a fast afterhyperpolarization in rat hippocampal pyramidal cells. J Physiol (Lond) 385:733-759.

Storm JF (1988) Temporal integration by a slowly inactivating $\mathrm{K}^{+}$current in hippocampal neurons. Nature 336:379-381.

Storm JF (1993) Functional diversity of $\mathrm{K}^{+}$currents in hippocampal pyramidal meurons. Semin Neurosci 5:79-92.

Streit P, Thompson SM, Gähwiler BH (1989) Anatomical and physiological properties of GABAergic neurotransmission in organotypic slice cultures of rat hippocampus. Eur J Neurosci 1:603-615.

Thompson SH (1977) Three pharmacologically distinct potassium channels in molluscan neurones. J Physiol (Lond) 265:465-488.

Wu RL, Barish ME (1992) Two pharmacologically and kinetically distinct transient potassium currents in cultured embryonic mouse hippocampal neurons. J Neurosci 12:2235-2246. 